\title{
Hydrolytic enzymes in sewage sludge treatment: A mini-review
}

\author{
Jo E Burgess and Brett I Pletschke* \\ Department of Biochemistry Microbiology and Biotechnology, Rhodes University, Grahamstown 6140, South Africa
}

\begin{abstract}
Biological wastewater treatment processes can be classified as either aerobic or anaerobic. These two biological treatment processes are each characterised by groups of micro-organisms and their associated enzymes. Hydrolytic enzymes secreted by these micro-organisms are vital for the rate-limiting step of hydrolysis in the treatment of highly polymeric substrates present in sewage sludge. In this mini-review, the effects of mass transfer limitation, metabolic intermediates, extracellular polymeric substances (EPS), electron acceptor conditions and $\mathrm{pH}$ and temperature on the activity of these enzymes are summarised. The most salient and current perspectives of the significance and the role that hydrolytic enzymes play in sewage sludge treatment are highlighted.
\end{abstract}

Keywords: EPS, floc, hydrolases, $\mathrm{pH}$, sewage, sludge, temperature

\section{Introduction}

Wastewater treatment processes can be divided into three classes; physical, chemical and biological. Biological treatment processes, in turn, can be classified as either aerobic or anaerobic. Each of these two classes of wastewater treatment has distinct associated advantages and disadvantages (Table 1). From an enzymatic point of view, aerobic and anaerobic processes are each characterised by groups of micro-organisms and their associated enzymes. The goal of this mini-review is to summarise the effects of mass transfer limitation, metabolic intermediates, EPS, electron acceptor conditions and $\mathrm{pH}$ and temperature on the activities of hydrolytic enzymes in sewage sludge treatment. The most salient and current perspectives on the significance and the role that hydrolytic enzymes play in sewage sludge treatment are highlighted.

\section{Mass transfer limitations imposed by size restriction due to bacterial membrane dimensions}

The removal of organic matter by biological oxidation (e.g. in the activated sludge process) depends on the activity of a mixed population of heterotrophic organisms that is able to utilise either oxygen or nitrate as the terminal electron acceptor in their metabolic reactions (Nybroe et al., 1992). The target pollutants to be destroyed must undergo mass transfer into the bacterial cells in order to take part in metabolic reactions, but only monomeric and oligomeric substrates $(<1000$ Da molecular weight) are able to cross bacterial membranes through cell-specific active transport processes (Cadoret et al., 2002). Bacteria in the activated sludge degrade the complex organic matter (polymeric substrates such as proteins, lipids and carbohydrates) into low molecular-weight intermediates by the action of extracellular hydrolases (Nybroe et al., 1992). These low molecular-weight compounds are in turn assimilated by the cells and used as a source of energy and carbon. Stepwise depolymerisation (e.g. hydrolysis) of highly poly-

\footnotetext{
* To whom all correspondence should be addressed.

西 +27 46603 8081; fax: +27 466223984 ;

e-mail: B.Pletschke@ru.ac.za

Received 16 October 2007; accepted in revised form 3 June 2008.
}

meric substrates is usually the first and overall rate-limiting step for the mineralisation of organic matter in activated sludge and anaerobic digested sludge treatment systems (Frølund et al., 1995; Gessesse et al., 2003; Higuchi et al., 2005; Whiteley et al., 2002a).

These rate-limiting steps are central to several mathematical models that have been developed explaining the biochemistry of biological wastewater treatment processes and predicting plant performance to assist wastewater treatment plant design engineers. Such models are one of the most successful ways of translating biological phenomena into process design parameters. The models all utilise kinetic parameters based upon the initial wastewater breakdown rate - i.e. hydrolysis by exoenzymes. For example, early work on aerobic treatment led to the creation of the widely utilised Activated Sludge Model No. 1 (ASM1, Henze et al., 1987). This was a relatively basic model and has since been revised and expanded to create ASM2 and ASM2d, which include phosphorus removal (Henze et al., 1995, 1999) and later ASM3, in which biological substrate transport into cells and subsequent intracellular storage (i.e. bacterial membrane size restriction limitations) were proposed as the most important mechanism of carbon and nitrogen utilisation and hence removal from wastewater (Gujer et al., 2000). All of the ASMs use biological growth kinetics to describe the activity of the biomass, with increasing model complexity owing to the cumulative addition of model components such as different biochemical processes, each of which has its own kinetic parameters. The kinetic parameters are assumed not to change (i.e. are treated as constants), and are further assumed to depend on the process configuration, substrate type and quantity and mean cell retention time alone.

Another model often used to allow the modelling of anaerobic wastewater treatment processes is anaerobic digestion model no. 1 (ADM1) (Batstone et al., 2002). The problem with this generic model is that it makes use of some oversimplified reactions in solid degradation processes. Yasui et al. (2008) investigated a modified ADM1 structure for modelling municipal primary sludge hydrolysis. Based on the results obtained from this study, modifications in the model structure of ADM1 were proposed to improve the modelling of primary sludge solid degradation in anaerobic digesters. Three biodegradable fractions were classified in this modified model: 


\begin{tabular}{|c|c|c|c|}
\hline \multicolumn{4}{|c|}{$\begin{array}{c}\text { TABLE } 1 \\
\text { Advantages and disadvantages of some common wastewater treatment unit processes }\end{array}$} \\
\hline Process & Advantages & Disadvantages & Waste products \\
\hline $\begin{array}{l}\text { Aerobic suspended growth processes, e.g. } \\
\text { activated sludge: Widely used in a vari- } \\
\text { ety of modifications (contact stabilisation, } \\
\text { oxidation ditches, extended aeration, deep } \\
\text { shaft etc). Vigorous aeration of flocs pro- } \\
\text { duces aerobic biological activity, followed } \\
\text { by sedimentation. }\end{array}$ & $\begin{array}{l}\text { Rapid purification possible at opti- } \\
\text { mum settings. Ideal for medium- } \\
\text { high strength organic wastes } \\
\text { containing natural pollutants, e.g. } \\
\text { meat processing, brewing, distill- } \\
\text { ery waste and sugar / starch waste. } \\
\text { Small footprint compared with, } \\
\text { e.g. aerobic ponding systems. }\end{array}$ & $\begin{array}{l}\text { Aeration and agitation rates } \\
\text { critical. Larger land areas } \\
\text { normally required than } \\
\text { when using, e.g. membrane } \\
\text { bioreactors. Sludge quality } \\
\text { critical (bulking \& rising } \\
\text { can occur). Can produce } \\
\text { malodours. }\end{array}$ & Sludge \\
\hline $\begin{array}{l}\text { Aerobic attached growth processes, e.g. } \\
\text { biological filtration: High rate, large sur- } \\
\text { face area plastic packings promote growth } \\
\text { of aerobic bacteria. Bed is irrigated using } \\
\text { fixed or rotary distributor, while natural or } \\
\text { forced air rises up through packing. 'Filtra- } \\
\text { tion' is a bad name. }\end{array}$ & $\begin{array}{l}\text { Low energy system. Widely used } \\
\text { for high rate roughing. Flexible by } \\
\text { virtue of packing top-up. }\end{array}$ & $\begin{array}{l}\text { Susceptible to biocides } \\
\text { and flies. Recycle may be } \\
\text { needed to ensure packing } \\
\text { wetted during periods of } \\
\text { low feed. }\end{array}$ & $\begin{array}{l}\text { Sludge from } \\
\text { downstream } \\
\text { clarifier. Odours } \\
\text { may need treat- } \\
\text { ing especially in } \\
\text { summer. }\end{array}$ \\
\hline $\begin{array}{l}\text { Aerobic attached growth processes, e.g. } \\
\text { rotating biological contactors (RBCs): } \\
\text { Consist of a shaft onto which are fitted large } \\
\text { diameter plastic sheet discs or cylindrical } \\
\text { cages containing random or plastic media. } \\
\text { The media is partly submerged in the efflu- } \\
\text { ent and the assembly is rotated slowly. }\end{array}$ & $\begin{array}{l}\text { Ideal where space is at a premium } \\
\text { and good for low and medium } \\
\text { strength effluents in large volumes. }\end{array}$ & $\begin{array}{l}\text { Can suffer mechanical } \\
\text { damage on start-up due } \\
\text { to the imbalanced loads } \\
\text { resulting from uneven } \\
\text { biofilm growth. }\end{array}$ & Sludge \\
\hline $\begin{array}{l}\text { Anaerobic suspended / attached growth } \\
\text { processes, e.g. high rate anaerobic sys- } \\
\text { tems: } \\
\text { Can be upflow and downflow filters, flu- } \\
\text { idised beds, sludge blankets etc. Oxygen } \\
\text { excluded to encourage growth of methano- } \\
\text { genic bacteria. }\end{array}$ & $\begin{array}{l}\text { Ideal for high strength organic } \\
\text { wastes containing natural pol- } \\
\text { lutants, e.g. meat processing, } \\
\text { brewing, distillery waste and } \\
\text { sugar/starch waste. Produces low } \\
\text { amounts of sludge. Possible to use } \\
\text { the methane as a fuel. }\end{array}$ & $\begin{array}{l}\text { Strong foul odours may } \\
\text { occur if reactors are not } \\
\text { isolated from the wider } \\
\text { environment. Long reten- } \\
\text { tion times needed so large } \\
\text { volume reactors required } \\
\text { compared with e.g. aerobic } \\
\text { systems with } 8 \mathrm{~h} \text { HRT. }\end{array}$ & $\begin{array}{l}\text { Biogas (valuable } \\
\text { by-product) and } \\
\text { high strength } \\
\text { sludge (also has } \\
\text { a commercial } \\
\text { value) }\end{array}$ \\
\hline
\end{tabular}

- An easily hydrolysable substrate with a degradation similar to that of slowly degradable compounds,

- A substrate fraction with a degradation similar to the lysis of a biomass fraction, and

- A substrate requiring disintegration before subsequent hydrolysis, which is representative of large-sized particles in primary sludge (Yasui et al., 2008).

\section{Extracellular enzymes: Ectoenzymes and exoenzymes}

Exoenzymes (such as lipases, glucosidases, proteases, etc.) (Table 2) (Frølund et al., 1995; Nybroe et al., 1992) can originate from one of three key sources, namelythe sewage influent; the activated sludge via cell autolysis; or as enzymes that are actively secreted by the cells. Furthermore, exoenzymes are either cell surface bound (ectoenzymes), in free form (exoenzymes) in water or adsorbed within the extracellular polymeric substances (EPS) of the sludge matrix (Cadoret et al., 2002; Frølund et al., 1995; Vavilin et al., 1996). Higuchi et al. (2005) have divided the extracellular enzymes in anaerobic digested sludge into two classes: 'cell-free enzyme' dispersed in the bulk liquid and 'cellbound enzyme' associated with the microbial cell surface. Using fluorescent in situ hybridisation, Higuchi et al. (2005) have indicated that cell-bound alpha-amylase is mainly responsible for the hydrolysis of digested sludge. The degree of contact between the microbial cells and their substrates is thus of crucial importance. Boczar et al. (1992) reported that the amount of exoenzymes dis- solved in water is negligible. Frølund et al. (1995) and Goel et al. (1998b) later reported that the hydrolases in sludge were mostly bacterial cell associated or floc associated (embedded in the EPS matrix), but not present in the bulk liquid. Guellil et al. (2001) demonstrated that the proteolytic activity in activated sludge flocs were mainly found in the EPS, while the glycolytic activity was associated with the organic colloidal fraction of the wastewater. Cadoret et al. (2002) then stated that the localisation of extracellular enzymes is not clearly established, and that the distribution of extracellular enzymes between the cell surface and the EPS is still quite unknown. Lastly, Whiteley et al. (2002a) showed that protease and phosphatase enzyme activities were predominantly associated with the organic particulate matter of the primary sewage sludge.

Exoenzyme activity is mostly confined to the hydrolase (Class 3) enzymes, most notably the lipases, phosphatases, glucosidases, and proteases (Boczar et al., 1992; Frølund et al., 1995; Nybroe et al., 1992). Jain et al. (1992) showed that the concentration of these hydrolases, and the contact that exists between these enzymes and their substrates, were very important in their modelling studies of complex particulate substrates during anaerobic digestion. Over a decade later, Novak et al. (2003) observed that the activity of these hydrolases declined during both aerobic and anaerobic digestion. Under aerobic conditions, however, a rapid loss of glucosidase activity over the first ten days was associated with a concomitant accumulation of polysaccharide material (Novak et al., 2003). In fact, a number of authors have shown the benefit of enzyme addition or pre-treatment on the 


\begin{tabular}{|c|c|c|c|c|}
\hline \multicolumn{5}{|c|}{$\begin{array}{c}\text { TABLE } 2 \\
\text { The Class } 3 \text { hydrolases of importance to wastewater treatment }\end{array}$} \\
\hline EC number* & Common nam & & Sludge type & Reference \\
\hline 3.1 .1 & \begin{tabular}{|l|} 
Lipases \\
\end{tabular} & \begin{tabular}{|l} 
Lipases \\
Lipases \\
Lipases \\
Lipases \\
Lipases \\
\end{tabular} & $\begin{array}{l}\text { Anaerobic-aerobic } \\
\text { Anaerobic } \\
\text { Anaerobic } \\
\text { Activated } \\
\text { Anaerobic (dairy) }\end{array}$ & $\begin{array}{l}\text { Goel et al. (1998a) } \\
\text { Whiteley et al. (2003a) } \\
\text { Whiteley et al. (2003b) } \\
\text { Gessesse et al. (2003) } \\
\text { Leal et al. (2006) }\end{array}$ \\
\hline 3.1 .3 & Phosphatases & $\begin{array}{l}\text { Acid phosphatase } \\
\text { Phosphatases }\end{array}$ & $\begin{array}{l}\text { Anaerobic-aerobic } \\
\text { Anaerobic }\end{array}$ & \begin{tabular}{|l|} 
Goel et al. (1998b) \\
Whiteley et al. (2002a) \\
\end{tabular} \\
\hline 3.2 .1 & Glucosidases & $\begin{array}{l}\alpha \text {-glucosidase } \\
\alpha \text {-glucosidase } \\
\alpha \text {-glucosidase } \\
\alpha \text {-amylase } \\
\alpha \text {-amylase } \\
\beta \text {-glucosidases } \\
\beta \text {-glucosidases } \\
\text { Amylases and } \alpha \text {-glucosidase }\end{array}$ & $\begin{array}{l}\text { Anaerobic-aerobic } \\
\text { Activated } \\
\text { Activated } \\
\text { Activated } \\
\text { Anaerobic digested } \\
\text { activated } \\
\text { Anaerobic } \\
\text { Anaerobic } \\
\text { Aerobic, anaerobic and anoxic }\end{array}$ & $\begin{array}{l}\text { Goel et al. (1998b) } \\
\text { Nybroe et al. (1992) } \\
\text { Cadoret et al. (2002) } \\
\text { Cadoret et al. (2002) } \\
\text { Higuchi et al. (2005) } \\
\text { Guellil et al. (2001) } \\
\text { Whiteley et al. (2003b) } \\
\text { Whiteley et al. (2002b) } \\
\text { Goel et al. (1998a) }\end{array}$ \\
\hline 3.4 & Proteases & $\begin{array}{l}\text { Protease } \\
\text { Protease } \\
\text { Protease } \\
\text { Protease } \\
\text { Protease } \\
\text { L-Leu-aminopeptidase } \\
\text { protease } \\
\text { alanine-aminopeptidase }\end{array}$ & $\begin{array}{l}\text { Anaerobic-aerobic } \\
\text { Anaerobic-aerobic anoxic } \\
\text { Activated } \\
\text { Activated } \\
\text { Anaerobic } \\
\text { Activated } \\
\text { Activated } \\
\text { Anaerobic } \\
\text { Activated }\end{array}$ & $\begin{array}{l}\text { Goel et al. (1998b) } \\
\text { Goel et al. (1998a) } \\
\text { Cadoret et al. (2002) } \\
\text { Guellil et al. (2001) } \\
\text { Whiteley et al. (2002a) } \\
\text { Cadoret et al. (2002) } \\
\\
\text { Gessesse et al. (2003) } \\
\text { Watson et al. (2004) } \\
\text { Nybroe et al. (1992) }\end{array}$ \\
\hline
\end{tabular}

*Enzyme Commission Number

conditioning of wastewater solids (primary sewage sludges) and enhancement of the degree of dewaterability of anaerobically digested biosolids (Ayol, 2005; Ayol and Dentel, 2005; Roman et al., 2006). Leal et al. (2006) have also used lipases in the enzymatic treatment of dairy wastewater. In contrast to restaurant wastes which have a uniquely high lipid content, general aerobic and anaerobic wastewater treatments are expected to contain a major organic fraction especially rich in protein and carbohydrate content (Goel et al., 1998b). Proteases and glycosidases are therefore believed to play a pivotal role in the degradation of wastewater sludges.

\section{Composition of wastewater treatment systems - the key role of metabolic intermediates, substrates and products}

Indeed, the suite of enzymes required may change and depend greatly on the composition of the wastewater influent. In addition, these enzyme activities may also change depending on the level of metabolic intermediates present in the treatment system. For example, Whiteley et al. (2002b; 2003b; 2004), and Watson et al. (2004) have shown that the activities of $\beta$-glucosidases and proteases in an anaerobic sulphidogenic bioreactor were stimulated by specific sulphur metabolites (e.g. sulphide: see Fig. 1), while these enzymes were inhibited by high levels of sulphate. Similarly, lipase activities in a standard rate anaerobic digester were also enhanced in the presence of sulphide and sulphite, and

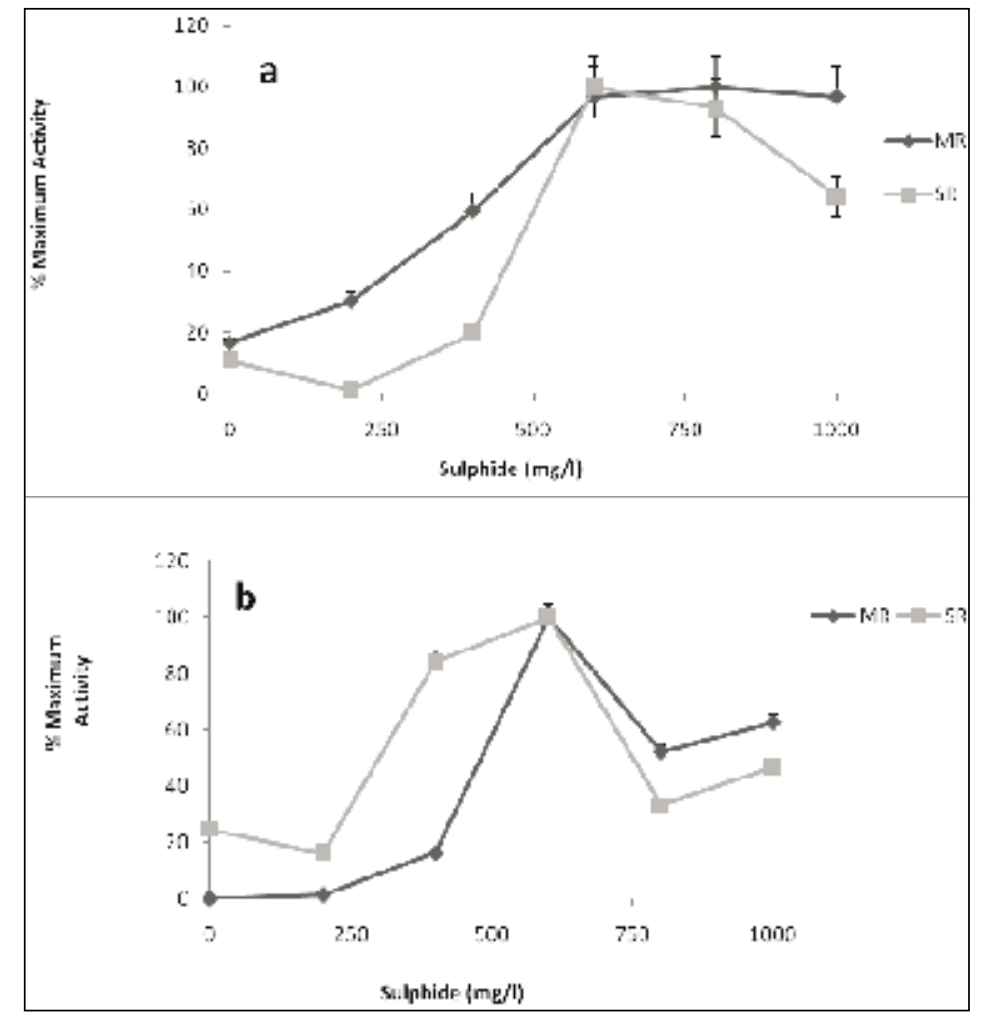

Figure 1

The effect of sulphide concentration on a) $\beta$-glucosidase and b) protease activities in a methanogenic bioreactor (MR) and sulphidogenic bioreactor (SR) 
inhibited by sulphate (Whiteley et al., 2003a; 2003b). The levels of substrate(s) and product(s) are also important. In enzymology, it is common for enzymes to be inhibited by their products, or to be stimulated by the presence of their substrates (substrate inhibition can; however, also occur at very high substrate concentrations). For example, the addition of hydrolysed starch was reflected by an increase in the $\alpha$-glucosidase activity of activated sludge (Nybroe et al., 1992). Furthermore, Frølund et al. (1995) have pointed to the fact that the presence of humic compounds in activated sludge may affect enzymatic activity. Also, it is possible for a metabolite to stimulate the activity of one enzyme while exerting an inhibitory effect on another. For example, Watson and Pletschke (2006) have shown that sulphide is able to stimulate the activity of $\beta$-glucosidases (a key hydrolase in the digestion of cellulose) while inhibiting the activity of $\alpha$-glucosidase (a key hydrolase in starch hydrolysis). On a genetic level, the gene expression of enzymes may also be related to the levels of substrates, products, and the levels of associated co-enzymes, cofactors or other metabolic intermediates in the microenvironment.

Designing wastewater treatment by running simulation models, which do not take enzyme expression and induction into account, leads to the model deviating from the real results and the consequence is that design engineers observe different results in the built process unit from those predicted by their pre-commissioning design calculations. To counteract this, biochemical models have been designed to incorporate enzyme induction and repression and metabolic changes. Zhang et al. (2002) proposed a model in which the protein synthesis system grows and decays, depending on the availability of the substrate. The growth rate of the sludge is then dependent on the rate of cell synthesis as determined by protein generation, and hence on the protein synthesis system. This link between biomass growth and substrate utilisation is very well known, but the way in which biological work is presented is not always accessible to the wastewater practitioner.

The production of new genetic material (ribosome synthesis) controls the growth rate of the bacteria in the sludge, and it is related to the availability (as differentiated from the concentration) of the substrate. It has been stated that kinetic parameters lumped together under the broad term 'endogenous decay' are in fact a wide range of cell biochemical reactions, such as endogenous respiration, maintenance energy requirements, cell lysis and decay and the effects of toxin or other deleterious physicochemical environmental aspects (Van Loosdrecht and Henze, 1999). Therefore, straightforward translation of oxygen uptake into substrate degradation is incorrect, as the rates of hydrolysis and oxidation are affected by substrate being enmeshed with the biomass, the storage of substrate products and the presence of slowly biodegradable COD (Gujer et al., 2000).

Cybernetic models have also been proposed to take enzyme production and activity into account (Lavallée et al., 2002). Cybernetic models simulate enzyme production and activation in bacteria in order to model the gain and loss of parts of the protein synthesis system; this was given the name 'resource machinery'. Cybernetic models include mathematical modelling of enzyme induction mechanisms as well as kinetic functions such as growth and respiration rates. Hence these models link enzyme synthesis and activity to the substrate available and have been shown to simulate chemostat cultures well. The impact of enzyme induction in denitrification in activated sludge was demonstrated by Lee et al. (2004), who used a cybernetic model proposed six years earlier (Liu et al., 1998). However, even this model only included one component to simulate short-term enzyme synthesis, and to include longer term protein synthesis (such as genetic material). Another, longer term time component must also be incorporated (Lavallée et al., 2002).

\section{The role of extracellular polymeric substances}

Several reports have suggested that the hydrolases are mainly localised in the extracellular polymeric substances (EPS) matrix of bacterial aggregates (Frølund et al., 1995; Guellil et al., 2001). The EPS originate from bacterial active secretion (Wawrzynczyk et al., 2007b) and from debris present in the sewage sludge itself. This debris can be either organic or inorganic (Tchobanoglous et al., 2003). Extracellular polymeric substances are composed of a variety of organic substances such as carbohydrates, proteins, humic compounds, lipids, uronic acids and deoxyribonucleic acids (Tchobanoglous et al., 2003). It is uncertain as to whether or not the EPS matrix assists or hinders the hydrolysis step. Tchobanoglous et al. (2003) have stated that EPS, together with multivalent ions, aid the formation and settling of sludge flocs in both aerobic and anaerobic sludge treatment systems. In contrast, Tchobanoglous et al. (2003) have also stated that an excess of EPS may hinder the dewatering of sludge, bio-flocculation and sludge settling (Liu and Fang, 2003; Tchobanoglous et al. 2003). Cadoret et al. (2002) stated that the diffusion of substrates in activated sludge flocs, and their subsequent availability to the extracellular enzymes may be hindered by this matrix. Cadoret and co-workers found that approximately $17 \%$ of L-Leu-aminopeptidase, $5 \%$ of alpha-glucosidase, $23 \%$ of protease and $44 \%$ of alpha-amylase activities were associated with the extracted EPS component of the flocs. In their studies, they examined the extent to which the diffusion of high molecular weight compounds through the EPS matrix in activated sludge aggregates reduced their availability to the extracellular enzymes (ectoenzymes and exoenzymes). The rate of amylose (azure) hydrolysis increased five-fold when the activated sludge flocs were dispersed by ultrasound and a cation exchange resin, indicating that amylose hydrolysis was indeed hampered by the presence of the EPS matrix. However, no change in the rate of protein (azocasein) hydrolysis was observed when the EPS matrix was dispersed. It appears therefore, from the work performed by Cadoret and coworkers, that the EPS matrix may hinder the accessibility of the substrates to the enzymes. In contrast to this observation, Ayol (2005), Frølund et al. (1995) and Vavilin et al. (1996) stated that the EPS may act as a trapping network that serves to confine the extracellular hydrolases, i.e. act as a sink for the immobilised enzymes (Frølund et al., 1995).

In order to study the hydrolases in wastewater sludges, the EPS matrix usually has to be dispersed in order to obtain and further purify the enzymes. This has been achieved using cation exchange resins (CER) alone, or in combination with the non-ionic detergent Triton X-100 (Gessesse et al., 2003). Triton $\mathrm{X}-100$ has also been used in combination with EDTA (ethylenediaminetetraacetic acid) for the extraction of lipases and proteases from activated sludge samples (Gessesse et al., 2003).

\section{The effects of various sludge pre-treatments}

Heat treatment has been used by Yan et al. (2008) for the reduction of excess sludge. This is a relatively simple process and the relationship between the efficiency of sludge reduction and biological response of the sludge matrix was investigated using microbial population and protease activity. Protease-secreting bacteria emerged shortly after heat treatment, with an instant 
increase in protease activity in the sludge supernatant after $1 \mathrm{~h}$ heat treatment. This protease activity was activity believed to have been released from the microbial cells via lysis (Yan et al., 2008).

Ultrasonic pre-treatment of sludge has also been used (Yu et al., 2008). Ultrasonic treatment can improve the aerobic digestibility of sludge, and therefore lead to enhanced sludge reduction. Yu and co-workers reported that ultrasonic pre-treatment enhanced the activities of various enzymes and promoted the shift of extracellular proteins, carbohydrates and enzymes from the inner layers of sludge flocs to the outer layers, leading to increased contact and interaction between these components and higher efficiencies in aerobic digestion. They also showed that ultrasonication effectively extracted the EPS from the sludge flocs, and that there existed no correlation between the biochemical composition of the EPS and the distribution of enzymes (such as proteases, alpha-amylases, alpha-glucosidases) within the sludge matrix (Yu et al., 2007).

Cation-binding agents such as sodium tripolyphosphate (STPP), citric acid (CA) or ethylenediaminetetraacetic acid (EDTA) have been used to improve the solubilisation of sludge (Wawrzynczyk et al., 2008). The cation-binding agents are believed to disrupt the adsorption of enzymes to the sludge matrix via polyvalent metal ions, thereby liberating the trapped or bound enzymes from the sludge structure. The increased availability of enzymes is believed to stimulate a more efficient release of organic matter from the sludge. Wawrzynczyk et al. (2007a) also investigated the effects of the cation-binding agents above (and others such as formic acid, citric acid, tartaric acid, Zeolite A, sodium fluoride, sodium thiosulphate and sodium silicate) on the solubilisation of municipal sludge and sludge structure (alone or in combination with enzymes-the treatment of the sludge with cation-binding agents was followed by the addition of three glycosidic enzymes). They reported that, once again, the use of the cation-binding agents above resulted in higher stability of the added enzymes and improved sludge digestion.

As mentioned previously, a number of authors have shown the benefit of enzyme addition or pre-treatment on the conditioning of wastewater solids (primary sewage sludges) and enhancement of the degree of dewaterability of anaerobically digested biosolids (Ayol, 2005; Ayol and Dentel, 2005; Roman et al., 2006). Kim and Sim (2004) optimised sludge pre-treatment in their study by controlling the amount of enzyme and ozone. Dursun et al. (2006) reported that there was a significant increase in cake solid content of anaerobically digested sludge ( $27 \%$ as opposed to $18 \%$ without enzyme pre-treatment) using an enzyme dose of $20 \mathrm{mg} / \ell$.

Sesay et al. (2006) also investigated enzyme hydrolysis as a mild and effective means of extracting extracellular polymers from mixed culture activated sludge flocs. Alpha-amylase, cellulase and proteinase were used in this study. Enzymatic extraction of the extracellular polymers was found to be quite rapid and only required a few hours. No significant cell lysis was observed. Proteins and carbohydrate components of the EPS were found to co-extract, indicating that these two components existed bound to each other in the sludge matrix. This enzyme extraction method, however, if compared to the traditional cation exchange resin method, generally results in a lower estimate of polymer content (Sesay et al., 2006).

\section{Different electron acceptor conditions}

Activated Sludge Model No. 2 recommends hydrolysis rates under anaerobic and anoxic conditions as $10 \%$ and $60 \%$ of the aerobic hydrolysis rates, respectively. There is a lack of consensus in literature regarding the rates of hydrolysis under different electron acceptor conditions. Goel et al. (1998a; 1998b) found that the effect of electron acceptor conditions on the hydrolases was significant for pure cultures (Bacillus amyloliquefaciens or Pseudomonas saccharophila), but only marginal for activated sludge. The activities of the hydrolases under the aerobic and anaerobic phases of a sequencing batch reactor were found to be roughly of the same magnitude, contradicting the assumptions of lower hydrolytic rates under anaerobic and anoxic conditions. Goel and co-workers have proposed that the enzymes that are floc-bound are recycled in single sludge systems and that steadystate (equilibrium) is established between enzyme synthesis and loss. They then studied the activities of four hydrolases (alkaline phosphatase, acid phosphatase, alpha-glucosidase and protease) under different electron acceptor conditions. These enzyme activities were each uniquely dependent on the following key considerations: rate of enzyme synthesis, stability of the enzymes involved and the location of the enzymes in the sludge. Goel et al. (1998b) concluded that these enzyme properties should be considered along with the treatment process layout in order to establish the reduction factors under different electron acceptor conditions.

\section{Temperature and $\mathrm{pH}$}

A great deal of effort is expended to maintain set conditions within process units. The operating $\mathrm{pH}$ range of most units is controlled in the range 6.5 to 8.5 , depending on the wastewater and the target pollutant. There is no such thing as an overall ideal operational $\mathrm{pH}$, since all processes employ consortia of micro-organisms, whose growth rates at different $\mathrm{pH}$ values are not the same. In addition, each species of micro-organism will use several different enzymes in its metabolic processes, and all of these also have varying $\mathrm{pH}$ optima. Hence the operational $\mathrm{pH}$ is a compromise, a value which can be tolerated by all enzymes and micro-organisms involved, but with a proportion of them showing activity at suboptimal level. The $\mathrm{pH}$ within sludge can change according to a range of processes which impact upon it: $\mathrm{CO}_{2}$ production (from aerobic respiration, growth and endogenous activity), $\mathrm{CO}_{2}$ removal (stripping via aeration in aerobic processes or surface stripping in anaerobic processes), uptake of ammonium or nitrate for growth or as an electron acceptor, and uptake of weakly acidic substrates for growth (e.g. acetate). Utilisation of substrates such as acetate consumes protons because the biomass maintains its cellular level charge (Gernaey et al., 2002). Conversely, the uptake of substrates such as dextrose, which are present in undissociated form, does not consume protons. The prevailing $\mathrm{pH}$ exerts an effect on almost all cellular processes: substrate uptake and storage, cell growth, degradation of storage products and endogenous processes.

Similarly, temperature influences almost all cellular reactions. In general, reactions proceed at faster rates under higher temperatures, but all enzymes have temperature optima and tolerance ranges below and above which substrate utilisation is slowed. The temperature effect can be modelled using the modified Arrhenius equation (Sin, 2004):

$$
r(T)=r\left(20^{\circ} C\right) \cdot \theta \cdot \cdot^{(T-20)}
$$

Where the temperature correction coefficient, $\theta$, can be found from the literature or determined experimentally for each biological process under consideration. 
Class 3 hydrolase enzyme kinetics (first order and rate-limiting)

(2) Affected by activators/ inducers (substrates), inhibitors (products), coenzymes, co-factors, metabolic intermediates: sulphide, (5) pH and temperature (i.e. environmental and operational parameters)

(4) AEROBIC VS. ANAEROBIC $\mathrm{e}^{-}$ACCEPTORS

Protein

Carbohydrate

Lipid

Amino acids

Monosaccharides

Volatile fatty acids

Long chain fatty acids Glycerol

(3) EPS (accessibility) and particle/floc size

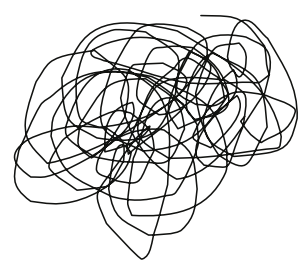

(1) Size restriction: $\leq$ MW 1000
Scheme 1

Physico-chemical and enzymatic components of the rate-limiting step of anaerobic digestion- hydrolysis. Mass transfer limitation (1), metabolic intermediates (2), EPS (3), electron acceptor conditions (4) and $\mathrm{pH}$ and temperature (5) all have a dramatic effect on the activity of the enzymes involved in wastewater treatment.
In contrast to the importance assigned to temperature control in biological / enzymological studies, wastewater treatment plant process designs are lumped into two very broad temperature categories: mesophilic and thermophilic. These two categories refer to broad ranges of operating temperatures, 20 to $40^{\circ} \mathrm{C}$ for mesophilic and 45 to $65^{\circ} \mathrm{C}$ for thermophilic operation. The temperature is important in determining the rates of reactions, especially hydrolysis and methane generation (for anaerobic units), but in practice temperature control may be only as precise as plus or minus one whole degree. Since a change of $10^{\circ} \mathrm{C}$ can approximately halve or double a reaction rate, or inhibit it completely, the permitted variability can have profound effects on process performance.

\section{Conclusions}

From an enzymatic point of view, aerobic and anaerobic processes are each characterised by groups of micro-organisms and their associated enzymes (many micro-organisms are facultative and can be active in both the environments; in this case, the hydrolytic enzymes are identical). Enzymes secreted or associated with these micro-organisms (especially the Class 3 hydrolases) are vital for the rate-limiting step of anaerobic digestion, hydrolysis (see Scheme 1). The activities of these hydrolases hold the key for establishing the overall limiting rate of the processes, and this rate limiting step involves the breakdown of large polymeric substrates such as carbohydrates (cellulose, starch, proteins) into small low molecular compounds (glucose, amino acids, etc.) less than 1000 Daltons in size which are able to enter the bacterial cell and participate in its cellular metabolism (see Scheme 1). In aerobic treatment processes, these hydrolases are usually free in the medium or contained within an EPS matrix. In the case of anaerobic treatment processes, these enzymes may be free in the extracellular environment, or in the case of carbohydrate degrading enzymes (glycohydrolases) contained and immobilised within a large multi-enzyme containing catalytic complex called a cellulosome (only present in some bacteria). Enzymes are often more stable when immobilised onto solid media such as substrate, EPS and floc particles, and the physical effect of these components on the enzyme can also not be ignored (Scheme 1).

\section{References}

AYOL A (2005) Enzymatic treatment effects on dewaterability of anaerobically digested biosolids-I: Performance evaluations. Process Biochem. 40 (7) 2427-2434.

AYOL A and DENTEL SK (2005) Enzymatic treatment effects on dewaterability of anaerobically digested biosolids-II: Laboratory characterizations of drainability and filterability. Process Biochem. 40 (7) 2435-2442.

BATSTONE DJ, KELLER J, ANGELIDAKI I, KALYUZHNYI SV, PAVLOSTATHIS SG, ROZZI A, SANDERS WTM, SIEGRIST $\mathrm{H}$ and VAVILIN VA (2002) Anaerobic Digestion Model No. 1. (ADM1). IWA Scientific and Technical Report No. 11, IWA, ISBN: $1-900222-51-5$.

BOCZAR BA, BEGLEY WM and LARSON RJ (1992) Characterization of enzyme activity in activated sludge using rapid analyses for specific hydrolases. Water Environ. Res. 64 (6) 792-797.

CADORET A, CONRAD A and BLOCK J-C (2002) Availability of low and high molecular weight substrates to extracellular enzymes in whole and dispersed activated sludges. Enzyme Microb. Technol. 31 179-186.

DURSUN D, TURKMEN M, ABU-ORF M and DENTEL SK (2006) Enhanced sludge conditioning by enzyme pre-treatment: Comparison of laboratory and pilot scale dewatering results. Water Sci. Technol. 54 (5) 33-41.

FRøLUND B, GRIEBE T and NIELSEN PH (1995) Enzymatic activity in the activated-sludge floc matrix. Appl. Microbiol. Biotechnol. $\mathbf{4 3}$ 755-761.

GERNAEY K, PETERSEN B, NOPENS I, COMEAU Y and VANROLLEGHEM PA (2002) Modelling aerobic carbon source degradation processes using titrimetric data and combined respirometrictitrimetric data: Experimental data and model structure. Biotechnol. Bioeng. 79 741-753.

GESSESSE A, DUEHOLM T, PETERSEN SB and NIELSEN PH (2003) Lipase and protease extraction from activated sludge. Water Res. 37 3652-3657.

GOEL R. MINO T, SATOH H and MATSUO T (1998a) Comparison of hydrolytic enzyme systems in pure culture and activated sludge under different electron acceptor conditions. Water Sci. Technol. 37 (4-5) 335-343.

GOEL R, MINO T, SATOH H and MATSUO T (1998b) Enzyme activities under anaerobic and aerobic conditions in activated sludge sequencing batch reactor. Water Res. 32 (7) 2081-2088.

GUELLIL A, BOUALAM M, QUIQUAMPOIX H, GINESTET P, AUDIC JM and BLOCK JC (2001) Hydrolysis of wastewater 
colloidal organic matter by extracellular enzymes extracted from activated sludge flocs. Water Sci. Technol. 43 (6) 33-40.

GUJER W, HENZE M, MINO T and VAN LOOSDRECHT MCM (2000) Activated Sludge Model No.3. In: Henze M, Gujer W, Mino $\mathrm{T}$ and Van Loosdrecht MCM (eds.) Activated Sludge Models ASMI, $A S M 2, A S M 2 D$ and ASM3. IWA Scientific and Technical Report 9. IWA Publishing, Caxton House, London.

HENZE M, GRADY CPL (Jr), GUJER W, MARAIS GvR and MATSUO T (1987) Activated Sludge Model No. 1. IAWQ Scientific and Technical Report No. 1, London, UK.

HENZE M, GUJER W, MINO T, MATSUO T, WENTZEL MCM and MARAIS GvR (1995) Activated Sludge Model No. 2. IAWQ Scientific and Technical Report No. 3, London, UK.

HENZE M, GUJER W, MINO T, MATSUO T, WENTZEL MC, MARAIS GvR and VAN LOOSDRECHT MCM (1999) Activated sludge model No. 2D, ASM2D. Water Sci. Technol. 39(1) 165-182.

HIGUCHI Y, OHASHI A IMACHI H and HARADA H (2005) Hydrolytic activity of alpha-amylase in anaerobic digested sludge. Water Sci. Technol. 52 (1-2) 259-266.

JAIN S, LALA AK, BHATIA SK and KUDCHADKER AP (1992) Modelling of hydrolysis controlled anaerobic digestion. J. Chem. Technol. Biotechnol. 53 337-344.

KIM JR and SIM SJ (2004) Optimal conditions for improving enzyme pretreatment efficiency in sludge reduction process. Korean $J$. Micro. Biotechnol. 32 (2) 166-171.

LAVALLĒE B, LESSARD P and BESSER C (2002) Decay rate variability of heterotrophic active biomass. Water Sci. Technol. 46 (1-2) 423-430.

LEAL, MCMR FREIREDMG, CAMMAROTAM, and SANT'ANNA (Jr) GL (2006) Effect of enzymatic hydrolysis on anaerobic treatment of dairy wastewater. Process Biochem. 41 (5) 1173-1178.

LEE D-U, CASASǓS-ZAMBANA A, HAMILTON R, SVORONOVOS S, LEE S-I and KOOPMAN B (2004) Significance of denitrifying enxyme dynamics in biological nitrogen removal processes: a simulation study. Water Sci. Technol. 49 (5-6) 265-274.

LIU P-H, ZHAN G, SVORONOS SA and KOOPMAN B (1998) Diauxic lag from changing electron acceptors in activated sludge treatment. Water Res. 32 3452-3460.

LIU Y and FANG HHP (2003) Influences of extracellular polymeric substances (EPS) on flocculation, settling and dewatering of activated sludge. Crit. Rev. Environ. Sci. Technol. 33 (3) 237-273.

NOVAK JT, SADLER ME and MURTHY SN (2003) Mechanisms of floc destruction during anaerobic and aerobic digestion and the effect on conditioning and dewatering of biosolids. Water Res. 37 (13) 3136-3144.

NYBROE O, JØRGENSEN PE and HENZE M (1992) Enzyme activities in waste water and activated sludge. Water Res. 26 (5) 579-584.

ROMAN HJ, BURGESS JE and PLETSCHKE BI (2006) Enzyme treatment to decrease solids and improve digestion of primary sewage sludge. Afr. J. Biotech. 5 (10) 963-967.

SESAY ML, ÖZCENGIZ G and DILEK SANIN F (2006) Enzymatic extraction of activated sludge extracellular polymers and implications on bioflocculation. Water Res. 40 (7) 1359-1366.

SIN G (2004) Systematic Calibration of Activated Sludge Models. Ph.D. Thesis. Applied Biological Sciences: Environmental Technology, Ghent University, Gent, Belgium.

TCHOBANOGLOUS G, BURTON FL and STENSEL HD (2003) In: Jones EA (ed.) Wastewater Engineering Treatment and Reuse. Metcalf and Eddy Inc. McGraw-Hill, New York.
VAN LOOSDRECHT MCM and HENZE M (1999) Maintenance, endogenous respiration, lysis, decay and starvation. Water Sci. Technol. 39 (1) 107-117.

VAVILIN VA, RYTOV SV and LOKSHINA LY (1996) A description of hydrolysis kinetics in anaerobic degradation of particulate organic matter. Bioresour. Technol. 56 229-237.

WATSON SD, AKHURST T, WHITELEY CG, ROSE PD and PLETSCHKE BI (2004) Primary sludge floc degradation is accelerated under biosulphidogenic conditions. Enzymological aspects. Enzyme Microb. Technol. 34 595-602.

WATSON SD and PLETSCHKE BI (2006) The effect of sulfide on $\alpha$-glucosidases: implications for starch degradation in anaerobic bioreactors. Chemosphere 65 159-164.

WAWRZYNCZYK J, RECKTENWALD M, NORRLÖW O and DEY ES (2008) The function of cation-binding agents in the enzymatic treatment of municipal sludge. Water Res. 42 (6-7) 1555-1562.

WAWRZYNCZYK J, RECKTENWALD M, NORRLÖW O and DEY ES (2007a) Solubilisation of sludge by combined chemical and enzymatic treatment. Afr. J. Biotechnol. 6 (17) 1994-1999.

WAWRZYNCZYK J, SZEWCZYK E, NORRLOW O and SZWAJCER DEY E (2007b) Application of enzymes, sodium tripolyphosphate and cation exchange resin for the release of extracellular polymeric substances from sewage sludge. Characterization of the extracted polysaccharides/glycoconjugates by a panel of lectins. J. Biotechnol. 130 274-281.

WHITELEY CG, HERON P, PLETSCHKE B, ROSE PD, TSHIVHUNGE S, VAN JAARSVELD FP and WHITTINGTON-JONES K (2002a) The enzymology of sludge solubilisation utilizing sulfate reducing systems. Properties of proteases and phosphatases. Enzyme Microb. Technol. 31 419-424.

WHITELEY C, PLETSCHKE B, ROSE P and NGESI N (2002b) Specific sulphur metabolites stimulate ß-glucosidase activity in an anaerobic sulphidogenic bioreactor. Biotechnol. Lett. 24 1509-1513.

WHITELEY CG, BURGESS JE, MELAMANE X, PLETSCHKE B and ROSE PD (2003a) The enzymology of sludge solubilization utilizing sulphate-reducing systems: The properties of lipases. Water Res. 37 289-296.

WHITELEY CG, ENONGENE G, PLETSCHKE BI, ROSE P and WHITTINGTON-JONES K (2003b) Co-digestion of primary sewage sludge and industrial wastewater under anaerobic sulphate reducing conditions: enzymatic profiles in a recycling sludge bed reactor. Water Sci. Technol. 48 (4) 129-138.

WHITELEY C, PLETSCHKE B, ROSE P, TSHIVHUNGE S, WATSON $\mathrm{S}$ and WHITTINGTON-JONES K (2004) Activation of proteases in an anaerobic sulphidogenic bioreactor. Biotechnol. Lett. 26 55-59.

YAN S, MIYANAGA K, XING X-H and TANJI Y (2008) Succession of bacterial community and enzymatic activities of activated sludge by heat-treatment for reduction of excess sludge. Biochem. Eng. J. 39 (3) 598-603.

YU G-H, HE P-J, SHAO L-M and ZHU Y-S (2008) Extracellular proteins, polysaccharides and enzymes impact on sludge aerobic digestion after ultrasonic pretreatment. Water Res. 42 (8-9) 1925-1934.

YASUI H, GOEL R, LI YY and NOIKE T (2008) Modified ADM1 structure for modelling municipal primary sludge hydrolysis. Water Res. 42 249-259.

YU G-H, HE P-J, SHAO L-M and LEE D-J (2007) Enzyme activities in activated sludge flocs (2007) Appl. Microbiol. Biotechnol. 77 (3) 605-612.

ZHANG X, DENNIS P, EHRENBERG M and BREMER H (2002) Kinetic properties of $r r n$ promoters in Escherichia coli. Biochimie 84 981-996. 
Available on website http://www.wrc.org.za ISSN 0378-4738 = Water SA Vol. 34 No. 3 July 2008

ISSN 1816-7950 = Water SA (on-line) 